\title{
Pollen nutrition in honey bees (Apis mellifera): impact on adult health
}

\author{
Bruna Estefânia Diniz Frias, Cosme Damião Barbosa, Anete Pedro Lourenço \\ Departamento de Ciências Biológicas, Faculdade de Ciências Biológicas e da Saúde, Universidade Federal dos Vales do \\ Jequitinhonha e Mucuri, Diamantina, Minas Gerais, Brazil
}

Received 8 February 2015 - Revised 21 April 2015 - Accepted 29 May 2015

\begin{abstract}
Pollen is the main protein source for honey bees, and its quality and digestibility are important factors for bee health. We compared the effects of eight different mixed-pollen diets on queenless adult survival and physiology. The mixtures represented the pollen source for bees in a natural environment. They consisted of three to five familial pollen types, and the protein percentage varied from 8.4 to $18.1 \%$. The mixtures that contained mainly Asteraceae pollen were less consumed and enhanced bee mortality, suggesting that this pollen type offers poor nutritional quality and assimilation for the bees. All pollen diets promoted ovarian activation, but among the pollentreated groups, the percentage of bees with activated ovaries was not related to the protein content of the diet, which suggests that ovarian activation may also depend on other nutrients. Survival was also positively correlated to the vitellogenin levels in the hemolymph. Our results showed that the amount of protein consumption and the pollen type influenced bee survival and physiology.
\end{abstract}

polyfloral pollen diet / ovary / hemolymph proteins / survival

\section{INTRODUCTION}

Honey bees (Apis mellifera L.) play an important role in biological communities as pollinators and have immense economic and ecological impact on crops and wild plants (Morse and Calderone 2000). Therefore, studies on honey bee health at the individual and colony levels are important. Several factors negatively impact bee and colony health, including pathogens (Cox-Foster et al. 2007), parasites such as Nosema microsporidia (Higes et al. 2009), pesticide exposure (Sanchez-Bayo and Goka 2014), poor nutrition (Brodschneider and Crailsheim

Electronic supplementary material The online version of this article (doi:10.1007/s13592-015-0373-y) contains supplementary material, which is available to authorized users.

Corresponding author: A. Lourenço, anete.lourenco@ufvjm.edu.br Manuscript editor: David Tarpy
2010), and the interactions of these factors (Potts et al. 2010). Nutrition deficiency and starvation are likely contributing reasons for colony losses around the world (vanEngelsdorp et al. 2009).

Angiosperm plant pollen and nectar are essential food sources for bees (Haydak 1970). Nectar is a carbohydrate source, whereas pollen is the primary protein source. In addition, pollen is also composed of carbohydrates, lipids, and various vitamins and minerals (Roulston and Cane 2000).

The pollen protein content from different plant species and regions varies widely $(2.5-61 \%$; Roulston et al. 2000), which yields different nutritive values for bees. Moreover, pollen digestion by bees may also vary among plant species. For example, the percentage of empty grains in the bee rectum was higher for pollen from Castanea (Fagaceae) than that from Trifolium (Fabaceae) (Crailsheim et al. 1992). These differences may be due to the differences in the pollen wall layer composition. The most superficial layer is the 
pollenkitt, which consists of lipids, proteins, and sugars. The next outer layer is the exine, which is composed of sporopollenin. The innermost layer is the intine and consists mainly of cellulose and pectin. In order to access the nutrient-rich cytoplasm, the bee must dismantle these layers surrounding it (for review Roulston and Cane 2000).

The availability, quality, and diversity of the pollen diet translate into the nutrients available to the colony and reflect bee health. Pollen quality can affect bee longevity (Schmidt et al. 1987), ovarian activation (Hoover et al. 2006; Human et al. 2007; Pirk et al. 2010), larva body size (Tasei and Aupinel 2008), and physiological metabolism (Alaux et al. 2011; Di Pasquale et al. 2013), whereas pollen diversity likely also plays an important role in immunity (Alaux et al. 2010; Di Pasquale et al. 2013).

Our research has focused on the influence of pollen quality (usually measured as protein content) and diversity (pollen-type composition) on the physiology and health of queenless adults. Pollen is mainly consumed by nurse bees and promotes development of the hypopharyngeal glands, the fat body, and the ovaries of these bees (Maurizio 1954; Dustmann and von der Ohe 1988). Ingestion of pollen or other protein-rich food is reflected in high protein levels in the hemolymph, which is often accompanied by high levels of storage proteins, such as vitellogenin $(\mathrm{Vg})$, the yolk protein, and hexamerins (Hex) (Bitondi and Simões 1996; Cremonez et al. 1998; Martins et al. 2008; Di Pasquale et al. 2013). These proteins are synthesized in the fat body and secreted into the hemolymph where they accumulate. Under queenless conditions, several workers activate their ovaries and lay haploid eggs (Velthuis 1970). The growing oocytes sequester $\mathrm{Vg}$, which is incorporated into the yolk during vitellogenesis (Engels et al. 1990). Hex levels likely play a role in reproduction because they positively correlate with ovarian activation in queenless workers (Martins et al. 2008; 2011). A link between pollen nutrition and ovarian activation was demonstrated in queenless workers exhibiting high or low levels of ovarian activation when fed high- or low-pollen diets, respectively (Hoover et al. 2006). Similarly, Human et al. (2007) showed that nourishment through high- quality pollen diets stimulates ovarian activation and egg development in honey bee workers.

Here, we used eight pollen mixtures collected by the honey bees in a natural environment to better understand the effects of a pollen diet on bees. We compared the quality and pollen-type composition of these diets and determined their impact on adult queenless bee survival, storage protein (Vg and Hex) synthesis, and ovarian activation. Studying the nutrition of pollen sources with different botanical origins may identify the best pollen types to enhance development and health.

\section{MATERIALS AND METHODS}

\subsection{Collection and analysis of bee pollen}

Bee pollen was collected using special pollen traps from Africanized A. mellifera hives in the Apiary of the Federal University of Jequitinhonha and Mucuri Valleys, Diamantina, Brazil. This apiary is located in a natural environment in a Brazilian savanna area ("Campos Rupestres", high-altitude rocky fields). The bee pollen loads were collected during the dry and wet seasons from 2009 to 2010 and then stored at $-20^{\circ} \mathrm{C}$ until use. The mixed pollen loads in a collection are referred to here as mixtures. Eight pollen mixtures were used for the treatments, and certain mixtures (mixtures 5 and 8) were hand-sorted by color to proportionally increase the amount of one or fewer pollen types. These mixtures were selected because they represent the pollen source for bees in the summer (wet season) and winter (dry season) in a natural environment. From the mixtures, a portion was separated for pollen-type identification and for measurement of the protein levels, and the remainder was used for the feeding treatments. The pollen spectrum of the mixtures was determined by examining microscope slides prepared using acetolyzed pollen grains in accordance to Erdtman's method (Erdtman 1960), in which nine parts acetic anhydride to one part concentrated sulfuric acid was used. The pollen type was identified using our reference collection of the local flora and a catalog of pollen grains of the Brazilian savanna (Bastos et al. 2000). The frequency of each pollen type was measured by counting $100-500$ pollen grains per slide (three slides mounted for each pollen sample). The nitrogen content was measured in $1 \mathrm{~g}$ of each pollen mixture using the Kjeldahl method 
(IAL 2008). The total nitrogen derived from the analysis was converted into protein by multiplying by 6.25 .

\subsection{Caged bee experiments}

Two experiments were performed using the adult Africanized honey bees. Experiment 1 was carried out in summertime (January 2010) using bees from three colonies maintained in the apiary of the University of São Paulo, Ribeirão Preto, Brazil. Experiment 2 was carried out in wintertime (May 2010) using bees from two colonies in the apiary of the Federal University of Jequitinhonha and Mucuri Valleys, Diamantina, Brazil. In both experiments, frames of sealed brood were kept in an incubator $\left(34{ }^{\circ} \mathrm{C}, 80 \%\right.$ relative humidity) where worker bees emerged. The newly emerged bees $(0-$ $16 \mathrm{~h}$ ) from the different colonies were mixed and randomly separated into groups for subsequent treatment.

In experiments 1 and 2, six and four groups of 40 newly emerged bees were used, respectively. These groups were separately confined in $8 \times 11 \times 13-\mathrm{cm}$ screened wooden cages, where they were maintained for 21 days in an incubator $\left(34^{\circ} \mathrm{C}\right.$ and $\left.80 \% \mathrm{RH}\right)$ under dark conditions. During this period, these bee groups were fed one of the following diets: (1) syrup prepared with $50 \%$ sugar in water (control) or (2) one of the mixtures of bee-collected pollen in the proportions $30 \%$ pollen mixture and $70 \%$ sugar (pollen and sugar were mixed until a dough was created). In experiment 1 , each of the five groups received mixtures 1 to 5 , and in experiment 2, three groups received mixtures 6 to 8 . Tap water was provided ad libitum to all groups.

In both experiments, each pollen-treated group received water in a $2.0-\mathrm{ml}$ vial for each cage and $1.5 \mathrm{~g}$ of the pollen diet. The water and food were replaced daily, and uneaten food was weighed to calculate the food and protein consumption. The control group received only water and syrup in a $2.0-\mathrm{ml}$ vial. The dead bees were scored and removed from the cages each day.

After 9 and 21 days of treatment, the control and pollen-treated bees were randomly collected for hemolymph extraction and ovary status examination. We collected after 9 and 21 days of treatment to investigate the short- and long-term effect of the pollen mixture diet. It is known that workers started to lay eggs 4 to 7 days after removal of the queen (Makert et al. 2006). As we aimed to investigate the influence of various sources of pollen on ovarian activation, 9 days of treatment was enough time to observe ovarian activation in queenless workers. Twelve to 18 bees were collected after 9 days of treatment and 3 to 18 bees were collected after 21 days. The number of samples from some groups was reduced due to the mortality after 21 days. The hemolymph samples were collected using a micropipette after making an incision in the abdominal cuticle, and they were then stored at $-20{ }^{\circ} \mathrm{C}$ until use. The hemolymph samples from three to four workers for each treatment were pooled. Each pool was considered a sample, and one to four samples were collected for each treatment. The ovaries were examined after the hemolymph sampling. The ovaries were classified as nonactivated if the ovarioles were slender and devoid of growing follicles, and the ovaries were considered activated if they contained growing follicles. The ovaries were categorized as stage I, with swollen ovarioles with visible vitellus but without distinct oocytes, stage II, with ovarioles containing distinct but immature oocytes, or stage III, with fully activated ovaries with mature oocytes. Non-activated ovaries and stages I, II, and III of activation were comparable to the previously categorized stages 1, 3, 4, and 5 (Hess 1942).

\subsection{Hemolymph protein profile using SDS-PAGE}

One-microliter hemolymph aliquots from pools were analyzed using SDS-PAGE. Electrophoresis was performed at $15 \mathrm{~mA}$ as described previously (Laemmli $1970)$ using $7.5 \%$ polyacrylamide gels $(100 \times 100 \times$ $1 \mathrm{~mm})$. After electrophoresis, the gels were stained with a Coomassie Brilliant Blue solution. The band intensities were quantified via densitometry using the Carestream Molecular Imaging software 5.x (Carestream Health, Inc.).

\subsection{Statistical analysis}

The amount of food and protein consumed per bee and the protein levels in the hemolymph were analyzed using one-way ANOVA and the Holm-Sidak test for post hoc comparisons. When the normality assumptions for ANOVA were not fulfilled, the analyses were performed using the Kruskal-Wallis test and Dunn's test for post hoc comparisons. Survival analyses were performed using a Kaplan-Meier log-rank test, considering the censored data of the bees that were alive at the end of study as well as the bees removed after 9 days for hemolymph extraction and ovary examination. The 
chi-square test was used to analyze the proportions of bees with activated (independent of the stage) and nonactivated ovaries between treatments and controls and between 9- and 21-day-old bees. Spearman correlations were calculated to determine the relationship among the mean survival of bees based on the Kaplan-Meier analyses, average food and protein consumption per caged adult bee, percentages of Asteraceae and Myrtaceae in the mixture (these pollen types were selected because they were the most frequent and/or present in most mixtures), pollen diversity (number of pollen types), average $\mathrm{Vg}$ and Hex titers, and the percentage of bees with activated ovaries. For the correlations, experiments 1 and 2 were analyzed together. The analyses were performed using Jandel SigmaStat 3.1 software (Jandel Corporation, USA).

\section{RESULTS}

\subsection{Pollen diet analysis}

The diets were analyzed for pollen type and protein content in all mixtures (mixtures 1 to 8 ) prepared to feed the bees. The mixtures consisted of three to five familial pollen types (Table I). Based on the pollen morphotypes, the mixtures varied from 5 (mixture 6) to 12 (mixture 3) different types. The protein percentages in the mixtures varied from 8.4 to $18.1 \%$, and the Asteraceae, Myrtaceae, and Moraceae pollen types were the most frequent (Table I).

\subsection{Influence of pollen nutrition on survival, ovarian activation, and hemolymph storage protein (Vg and Hex 70) levels in queenless workers}

To determine whether the group of bees consumed the same amount of pollen, we measured the volume of food consumed daily. Consumption of mixture 1 was lower than that of mixture 2 in experiment 1 (one-way ANOVA, post hoc HolmSidak, $p=0.003$ ), and in experiment 2 , the consumption of mixture 8 was lower compared to that of mixture 6 (one-way ANOVA, post hoc HolmSidak, $P=0.002$ ) (Online Resource 1). Bees fed mixtures 2 and 4 ingested more protein than the bees fed the other mixtures in experiment 1 (one- way ANOVA, post hoc Holm-Sidak, $P \leq 0.01$ ), and in experiment 2 , the bees fed mixture 6 ingested more protein than the bees fed mixtures 7 (one-way ANOVA, post hoc Holm-Sidak, $P \leq$ 0.01 ) and 8 (one-way ANOVA, post hoc HolmSidak, $P=0.014$ ) (Online Resource 1).

The influence of different pollen mixtures on adult survival was further examined (Figure 1a, b). The bees fed mixture 1 exhibited the highest mortality compared with the other diets (control or pollen mixtures) in experiment 1 (Kaplan-Meier log-rank test, for all comparisons $P<0.01$; Figure 1a). The bees fed mixtures 2 and 4 exhibited better survival than the bees fed mixture 5 (Kaplan-Meier log-rank test, mixture 2 versus 5, $P=0.025$; mixture 4 versus $5, P=0.028$ ) but did not compared to the controls (KaplanMeier log-rank test, control versus mixture 2, $P=0.283$; control versus mixture $4, P=0.256$ ) and bees fed mixture 3 (Kaplan-Meier log-rank test, mixture 2 versus $3, P=0.246$; mixture 4 versus $3, P=0.217$ ). Mixture 8 resulted in higher mortality compared to all other groups in experiment 2 (Kaplan-Meier log-rank test, for all comparisons $P<0.01$; Figure $1 \mathrm{~b}$ ).

We then explored the relationships between diet (pollen nutrition) and ovarian activation. Because the worker bees used in this study were maintained without a queen, certain workers activated their ovaries. In both experiments 1 and 2, ovarian activation was only observed in bees fed pollen (Figure 2). Older bees showed proportionally more ovarian activation than young bees in experiment 1 (9- versus 21-day-old bees; experiment $1, \chi^{2}=7.426$, degree of freedom (d.f.) $=1$, $P=0.006$; experiment $2, \chi^{2}=1.385$, d.f. $=1, P=$ 0.239 ). Comparing only the bees fed pollen, no significant differences were observed among the bees fed mixtures, except the lowest ovarian activation observed in 9-day-old bees fed mixture 4 in experiment 1 (mixture 4 versus 1 and $2, \chi^{2}=$ 3.282 , d.f. $=1, P=0.07$; mixture 4 versus $3, \chi^{2}=$ 3.800 , d.f. $=1, P=0.05$; mixture 4 versus $5, \chi^{2}=$ 9.309 , d.f. $=1, P=0.002)$. Ovarian activation at the highest level (stage III) was observed in the 9-day-old bees fed mixes 2 and 5 (in experiment 1) and mixture 6 (in experiment 2), as well as the 21-day-old bees fed mixes 4 and 5 (experiment 1) and mixture 8 (experiment 2) (Figure 2). 
Table I. Pollen diet for feeding honey bees.

\begin{tabular}{|c|c|c|c|}
\hline Diet & Pollen collection period & Pollen types and frequency (\%) & $\begin{array}{l}\text { Protein percentage } \\
\text { in the pollen mixture }\end{array}$ \\
\hline Mix 1 & May 2009 (dry season) & $\begin{array}{l}\text { Asteraceae (five types) }-88.4 \\
\text { Myrtaceae-10.2 } \\
\text { Lamiaceae }-0.8 \\
\text { Cyperaceae }-0.6\end{array}$ & 13.3 \\
\hline Mix 2 & September 2009 (wet season) & $\begin{array}{l}\text { Myrtaceae (three types) }-54.3 \\
\text { Asteraceae (four types) }-21.2 \\
\text { Aquifoliaceae (two types) }-15.2 \\
\text { Cyperaceae }-9.3\end{array}$ & 15.9 \\
\hline Mix 3 & September 2009 (wet season) & $\begin{array}{l}\text { Myrtaceae (three types) }-45.0 \\
\text { Asteraceae (five types) }-24.5 \\
\text { Aquifoliaceae (two types) }-20.0 \\
\text { Cyperaceae }-8.0 \\
\text { Poaceae }-2.5\end{array}$ & 12.2 \\
\hline Mix 4 & September 2009 (wet season) & $\begin{array}{l}\text { Myrtaceae (two types) }-44.2 \\
\text { Asteraceae (three types) }-34.6 \\
\text { Aquifoliaceae-18.0 } \\
\text { Poaceae-16.0 } \\
\text { Euphorbiaceae-3.2 }\end{array}$ & 18.1 \\
\hline Mix 5 & $\begin{array}{l}\text { December } 2009 \text { (wet season) } \\
\text { (sorted by color) }\end{array}$ & $\begin{array}{l}\text { Asteraceae (three types) }-39.8 \\
\text { Fabaceae }-27.8 \\
\text { Cyperaceae-27.0 } \\
\text { Myrtaceae-3.2 } \\
\text { Solanaceae-2.2 }\end{array}$ & 8.4 \\
\hline Mix 6 & March 2010 (wet season) & $\begin{array}{l}\text { Moraceae-62.0 } \\
\text { Asteraceae (two types)-25.0 } \\
\text { Velloziaceae-11.2 } \\
\text { Amaranthaceae-1.8 }\end{array}$ & 15.9 \\
\hline Mix 7 & May 2009 (dry season) & $\begin{array}{l}\text { Asteraceae (five types) }-77.5 \\
\text { Malpighiaceae-13.0 } \\
\text { Myrtaceae (two types) }-9.5\end{array}$ & 10.7 \\
\hline Mix 8 & $\begin{array}{l}\text { October } 2009 \text { (wet season) } \\
\text { (sorted by color) }\end{array}$ & $\begin{array}{l}\text { Asteraceae (three types) }-55.8 \\
\text { Fabaceae-28.0 } \\
\text { Myrtaceae-10.4 } \\
\text { Velloziaceae-5.8 }\end{array}$ & 17.7 \\
\hline
\end{tabular}

We also investigated the abundance of $\mathrm{Vg}$ and Hex 70 proteins in the hemolymph from bees fed the different diets. In experiment 1, 9-day-old bees fed the pollen mixtures showed the highest levels of $\mathrm{Vg}$ compared to the control (syrup) group (oneway ANOVA, post hoc Holm-Sidak, $P<0.001$ ), except the bees fed mixture 5 (one-way ANOVA, post hoc Holm-Sidak, $P=0.669$ ) (Figure $3 \mathrm{a}, \mathrm{b}$ ).
In experiment 2, 9-day-old bees fed mixture 6 showed higher levels of Vg compared to the control (one-way ANOVA, post hoc Holm-Sidak, $P=0.003$ ) (Figure 3a, b). The highest levels of Hex 70 were observed in the bees fed pollen mixtures in experiment 1 (one-way ANOVA, post hoc Holm-Sidak, $P<0.01$ ) but not in the bees fed mixture 5 (one-way ANOVA, post hoc Holm- 
a

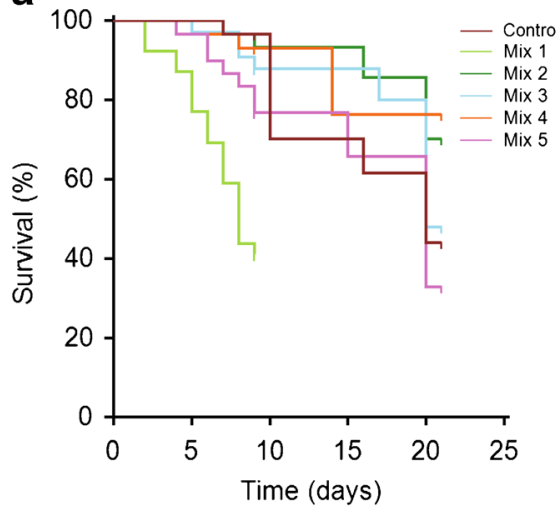

b

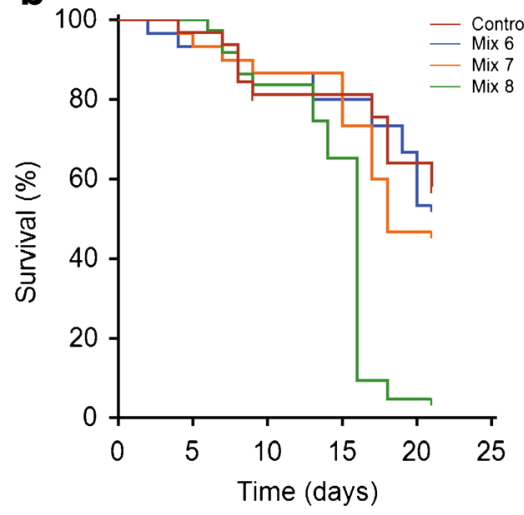

Figure 1. Effects of pollen mixtures on adult survival. Survivorship of caged worker bees fed different pollen mixtures diets (mixes 1 to 8 ) and syrup (control) over 21 days. Two independent experiments were conducted: experiment 1 (a) with pollen mixtures 1 to 5 and experiment 2 (b) with pollen mixtures 6 to 8 .
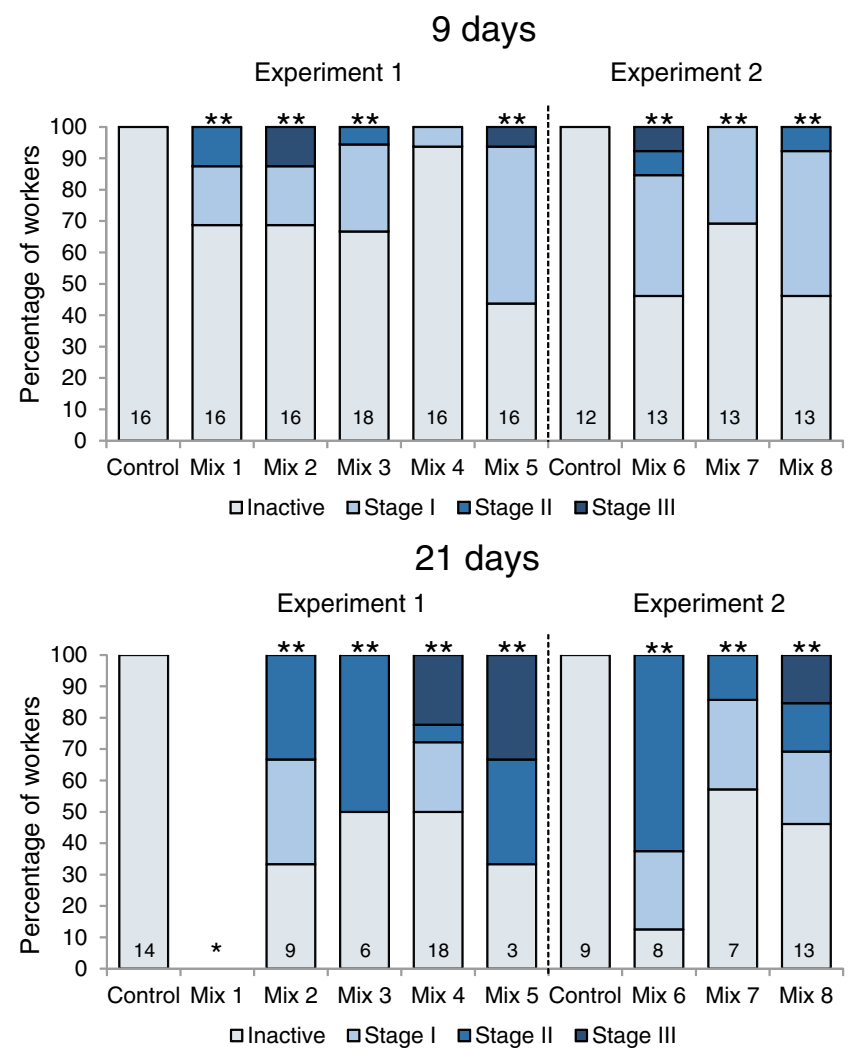

Figure 2. Effects of pollen mixtures on ovarian activation. Percentage of workers with inactive or active ovaries (stages I, II, and III) in queenless bees fed syrup (control) or pollen mixtures (experiment 1, mixes 1 to 5, experiment 2, mixes 6 to 8 ) after 9 and 21 days of treatment. An asterisk indicates that no sample was analyzed. Two asterisks indicate that the percentage of bees with activated ovaries was significantly different compared with the control group ( $\chi^{2}$ test; $P<0.05$ ). The values inside the bar represent the number of analyzed honey bees. 
Sidak, $P=0.405$ ) (Figure 3a, c). Control older bees (21 days old) exhibited lower levels of $\mathrm{Vg}$ $(t$ test $=30.508$, d.f. $=3, P<0.001)$ and Hex 70A $(t$ test $=7.106$, d.f. $=3, P=0.006)$ in the hemolymph compared to the control 9-day-old bees in experiment 1 (Figure 3b, c). Conversely, older bees fed pollen exhibited increased $\mathrm{Vg}$ (experiment 1, Kruskal-Wallis, post hoc Dunn's test, $P=0.023$, and experiment 2, one-way ANOVA, post hoc Holm-Sidak, $P=0.006$ ) and Hex 70 (experiment 2 , one-way ANOVA, post hoc Holm-Sidak, $P<0.001$ ) levels (Figure 3b, c).

A positive correlation was observed between the average survival and the average amount of protein consumption ( 9 days old $r=0.683, P=$ 0.047 ; 21 days old $r=0.762, P=0.021$ ), and a negative correlation was observed for the average survival and percentage of Asteraceae in the mixture $(9$ days old $r=-0.719, P=0.037 ; 21$ days old $r=-0.786, P=0.025$ ) (Online Resource 2). A negative correlation was observed for the average amount of food consumption and the percentage of Asteraceae ( 9 days old $r=-0.857, P=0.002$ ). The percentage of Myrtaceae in the mixtures was positively correlated with mean survival ( 9 days old $r=0.850, P=0.002$ ). The average survival was also correlated with the $\mathrm{Vg}$ amount in 21day-old bees $(r=1, P<0.001)$. The average titers of $\mathrm{Vg}$ and Hex 70 were positively correlated in 9day-old bees $(r=1, P<0.001)$. The average amount of consumed food was correlated with the average $\mathrm{Vg}$ and Hex 70 titers in 21-day-old bees (for both proteins, $r=0.893, P<0.001$ ). The percentage of bees with activated ovaries was not correlated with any parameter tested (Table S1).

\section{DISCUSSION}

In this study, we evaluated the survival and physiology of adult queenless bees fed different mixed pollen diets. The results show that the pollen-type composition and nutrition quality of the diet influenced bee physiology and health.

The diets offered to the bees consisted of pollen collected by foragers in a "Campos Rupestres" (high-altitude rocky fields) physiognomy. In this physiognomy, the vegetation comprised many plant species (Rapini et al. 2008), and the quality of the bee-collected pollen was analyzed in this natural environment. The majority of the pollen mixtures provided to the bees primarily consisted of Asteraceae, Moraceae, and Myrtaceae as the most abundant pollen types, which indicates that they were preferentially collected by the foragers. In general, the protein amount in the mixtures from the dry and wet seasons was relatively low compared to the protein levels of several familial types (Roulston et al. 2000).

The adult bees from different sources reared in different seasons (experiments 1 and 2) responded similarly to the pollen quality and type. The mean survival was positively related to the mean amount of protein consumed per bee and negatively related to the percentage of Asteraceae in the mixture. In fact, low survival was observed in adult workers provided diets containing Asteraceae (mixtures 1 and 8) as the most abundant pollen type. This pollen type was also unpalatable to the bees because food consumption was negatively correlated with the percentage of Asteraceae in the mixture (Online Resource 2), resulting in lower ingestion of protein. The protein content is commonly used to measure pollen quality. The protein levels of Asteraceae pollen are usually low compared with other familial pollen types (Roulston et al. 2000). However, the protein percentage of the Asteraceae diets used in this study varied from the lowest ( $8 \%$, mixture 5$)$ to the highest (18\%, mixture 8$)$ levels. The amounts of essential amino acids are also a factor for measuring pollen quality. The pollens from dandelion (Asteraceae) and sunflower (Asteraceae) are deficient in several essential amino acids, and because of this, they are considered poor pollen for bees (Loper and Cohen 1987; Nicolson and Human 2013). Moreover, the nutritional value of pollen for bees also depends on their digestion, and Asteraceae pollen has low rates of digestion (Peng et al. 1985; Roulston and Cane 2000; Human et al. 2007). Asteraceae pollenkitt or chemicals therein may interfere with its digestion and result in low digestion efficiency and nutrient assimilation in honey bees (Human et al. 2007) and solitary bees (Williams 2003; Praz et al. 2008). Therefore, the pollen structure and amino acid composition of Asteraceae associated with its low ingestion, and consequently low protein ingestion, may be responsible for the decreased 
a
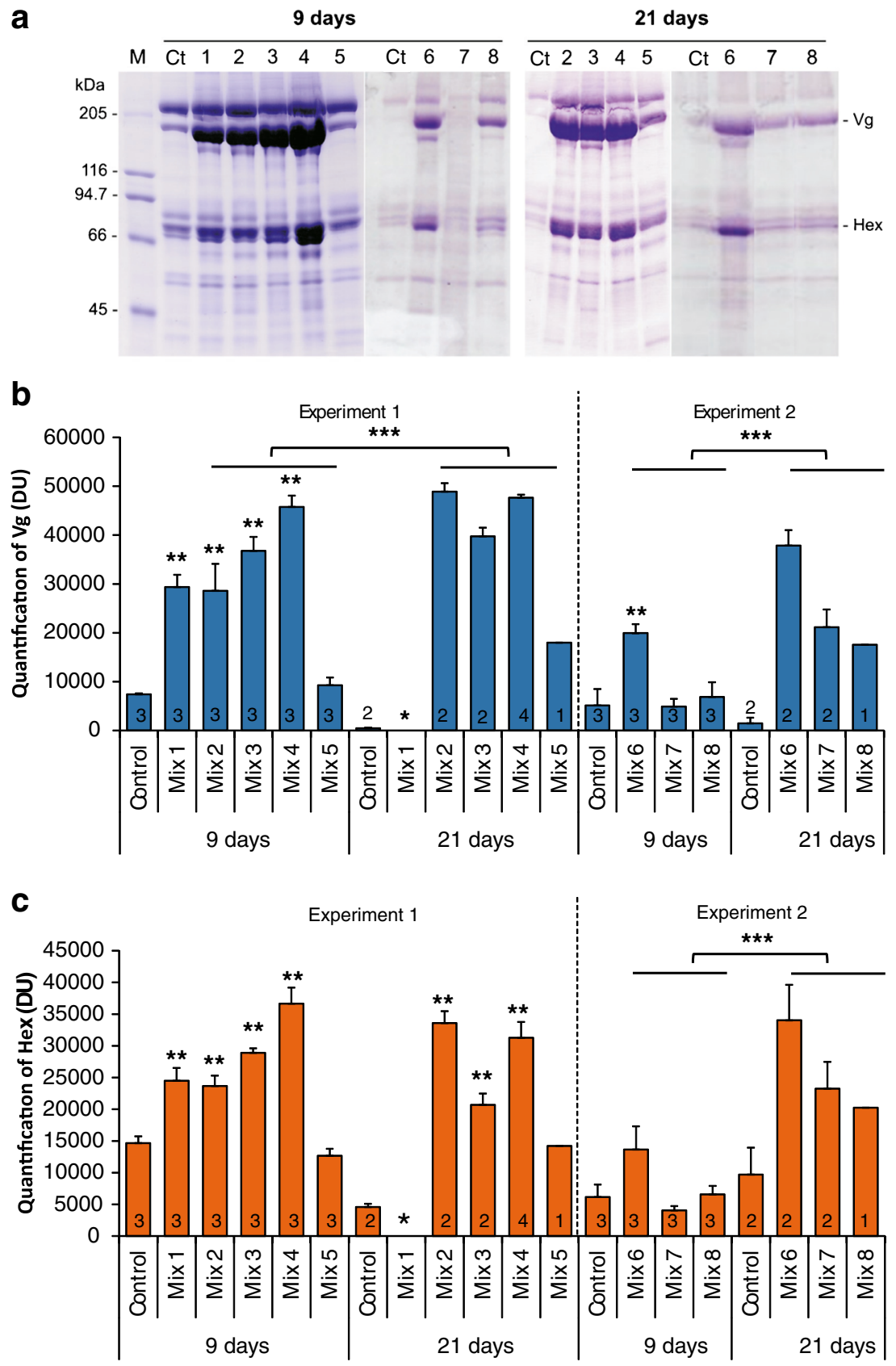

survival. By contrast, bees fed a diet with Myrtaceae as the most abundant pollen type showed greater survival (positive correlation with mean survival in 9-day-old bees; Online Resource 2), which suggests that this pollen type offers better nutritional digestibility and assimilation to the bees.

Pollen, as the main protein source for bees, may vary in morphology and consequently in its digestion and chemical composition, which 
Figure 3. Effects of pollen mixtures on adult storage protein levels. Vg and Hex protein expression in the hemolymph of caged adults fed syrup (control) or one of the pollen mixtures (mixes 1 to 5 in Experiment 1 and mixes 6 to 8 in experiment 2) after 9 and 21 days of treatment. a Coomassie Brilliant Blue-stained SDSpolyacrylamide gel representative of one sample. Each sample corresponds to a pool of hemolymph from four bees. b, c The graphs represent arbitrary densitometry units (DU) derived from expression of the proteins $\mathrm{Vg}$ and Hex in one to four samples (one sample is shown in a). Each sample corresponds to a pool of hemolymph from four bees, except samples from 21-day-old bees (mixes 3, 5, 6, and 7) with pools of hemolymph from three bees. The number of samples is indicated in the bar graphs. Data shown as mean values $\pm \mathrm{SE}$. An asterisk indicates that no sample was analyzed. Two asterisks indicate that protein levels were significantly different compared to the control group (one-way ANOVA and Holm-Sidak post hoc test; $P<0.05)$. Three asterisks indicate that the protein levels were significantly different between groups of 9- and 21-day-old bees (one-way ANOVA and Holm-Sidak post hoc test in b experiment 2 and $\mathbf{c}$ experiment 2 and Kruskal-Wallis and Dunn's post hoc test in $\mathbf{b}$ experiment $1 ; P<0.05$ ).

influence ovarian activation (Pernal and Currie 2000; Human et al. 2007). In our experiments, only bees fed pollen mixtures showed activation of ovaries. Ovarian activation was observed as early as 9 days after treatment, and the percentage of bees with active ovaries was higher after 21 days. However, there is no correlation between nutrition, such as the pollen composition and protein content of the diet, and the percentage of bees with activated ovaries. These results suggest that ovarian activation may also depend on other pollen nutrients, such as lipids and carbohydrates. The importance of an optimal balance of nutrients for survival and ovarian activation in honey bees was previously described (Altaye et al. 2010; Pirk et al. 2010). They studied artificial diets comprising various protein to carbohydrate proportions and observed longer survival in bees fed a lower protein/carbohydrate ratio, but higher ovarian activation was observed on royal jelly diets, mainly due to the presence of other nutrients in addition to protein.

Interestingly, a high percentage of 21-day-old bees fed mixture 4 showed activated ovaries, overcoming the low-activation ovaries in 9-dayold bees compared to the other groups. These data indicate that the relationship between food and ovarian activation also depends on the age of the bee and treatment period.

Increased $\mathrm{Vg}$ synthesis is observed in workers with activated ovaries, and this protein is incorporated into the growing oocytes (Engels et al. 1990). Furthermore, Hex 70a levels also increase in these workers, which suggest a role in reproduction (Martins et al. 2008; 2011). We also observed higher levels of $\mathrm{Vg}$ and Hex 70 in pollen-treated groups with bees showing activated ovaries compared to the control bees. Moreover, we observed higher levels of $\mathrm{Vg}$ and Hex 70 in 21-day-old queenless workers, when the bees showed greater ovarian activation.

Vg (Bitondi and Simões 1996) and Hex 70a (Martins et al. 2008) accumulation in adult honey bee worker hemolymph also depends on the amount of proteins that they consume, resulting in low levels of $\mathrm{Vg}$ and Hex if there is a lack or shortage of pollen in the diet. The relationship between these storage proteins levels and the amount of protein consumption was observed in 21-day-old bees, supporting the hypothesis that a proteinaceous diet promotes higher levels of storage proteins in the hemolymph. A positive correlation was observed between the mean Vg levels and mean survival in 21-day-old bees (Online Resource 2). This result confirms the importance of this protein for worker longevity (Nelson et al. 2007).

In conclusion, this study reports that the pollen diet quality influences bee physiology and survival. The amount of protein consumption influences adult survival, and certain pollen types are more detrimental than others. Bees fed mixtures with Asteraceae pollen as the main pollen showed decreased survival compared to other mixtures, which indicates that pollen morphology and chemical composition may contribute to its nutritional quality. Nutritional studies using pollen collected by the bees are important for determining the availability and diversity of resources in areas where bees pollinate, as well as for evaluating the consequences for bee health. 


\section{ACKNOWLEDGMENTS}

We are grateful to Dr. Rodrigo D Silveira for supplying the pollen and Luiz R Aguiar for expert assistance with the bees. We thank Dr. Nísia AVD Pinto, who allowed us to use her laboratory to perform the pollen protein quantification, and Dr. Zilá LP Simões and Dr. Márcia MG Bitondi for providing us the opportunity to perform certain experiments in their laboratory and two anonymous reviewers for their valuable comments on the manuscript. Financial support was granted by the Fundação de Amparo a Pesquisa do Estado de Minas Gerais (FAPEMIG CBB-APQ-00680-09).

\section{Alimentation en pollen par les abeilles ( Apis mellifera ): son rôle sur la santé des adultes}

régime pollinique multifloral / ovaire / protéines de l'hémolymphe / survie

Pollenernährung bei Honigbienen (Apis mellifera): Auswirkungen auf die Gesundheit der Erwachsenen

Polyflorale Pollennahrung / Ovarien / Hämolymphproteine / Überleben

\section{REFERENCES}

Alaux, C., Brunet, J.L., Dussaubat, C., Mondet, F., Tchamitchan, S., Cousin, M., Brillard, J., Baldy, A., Belzunces, L.P., Le Conte, Y. (2010) Interactions between Nosema microspores and a neonicotinoid weaken honeybees (Apis mellifera). Environ. Microbiol. 12, 774-782

Alaux, C., Dantec, C., Parrinello, H., Le Conte, Y. (2011) Nutrigenomics in honey bees: digital gene expression analysis of pollen's nutritive effects on healthy and varroa-parasitized bees. BMC Genomics 12, 496

Altaye, S.Z., Pirk, C.W.W., Crewe, R.M., Nicolson, S.W. (2010) Convergence of carbohydrate-biased intake targets in caged worker honeybees fed different protein sources. J. Exp. Biol. 213, 3311-3318

Bastos, E.M., Martins, L.A.P., Rodrigues, M.L., Soares, A.E.E. (2000) Pesquisas com plantas apícolas em Minas Gerais: banco de Imagens. Mensagem Doce $\mathbf{5 5}, 8-12$

Bitondi, M.M.G., Simões, Z.L.P. (1996) The relationship between level of pollen in the diet, vitellogenin, and juvenile hormone titres in Africanized Apis mellifera workers. J. Apic. Res. 35, 27-36

Brodschneider, R., Crailsheim, K. (2010) Nutrition and health in honey bees. Apidologie 41, 278-294
Cox-Foster, D.L., Conlan, S., Holmes, E.C., Palacios, G., Evans, J.D., et al. (2007) A metagenomic survey of microbes in honey bee colony collapse disorder. Science 318, 283-287

Crailsheim, K., Schneider, L.H.W., Hrassnigg, N., Bühlmann, G., Brosch, U., Gmeinbauer, R., Schöffmann, B. (1992) Pollen consumption and utilization in worker honeybees (Apis mellifera carnica): dependence on individual age and function. J. Insect Physiol. 38, 409-419

Cremonez, T.M., De Jong, D., Bitondi, M.M.G. (1998) Quantification of hemolymph protein as a method for testing protein diets for honey bees (Hymenoptera: Apidae). J. Econ. Entomol. 91, 1284-1289

Di Pasquale, G., Salignon, M., Le Conte, Y., Belzunces, L.P., Decourtye, A., Kretzschmar, A., Suchail, S., Brunet, J.L., Alaux, C. (2013) Influence of pollen nutrition on honey bee health: do pollen quality and diversity matter? PLoS ONE 8, e72016

Dustmann, J.H., von der Ohe, W. (1988) Einflu $\beta$ von Kälteeinbrüchen auf die Frühjahrsentwinklung von Bienenvölkern (Apis mellifera L). Apidologie 19, 245-254

Engels, W., Kaatz, H., Zillikens, A., Simões, Z.L.P., Trube, A., Braun, R., Dittrich, F. (1990) Honeybee reproduction: vitellogenin and caste-specific regulation of fertility. In: Hoshi, M., Yamashita, O. (eds.) Advances in Invertebrate Reproduction, pp. 495-502. Elsevier, Amsterdam

Erdtman, G. (1960) The acetolysis method. A revised description. Sven. Bot. Tidskr. 54, 561-564

Haydak, M.H. (1970) Honey bee nutrition. Annu. Rev. Entomol. 15, 143-156

Hess, G. (1942) Über den Einfluß der Weisellosigkeit und des Fruchtbarkeitsvitamins E auf die Ovarien der Bienenarbeiterin. Ein Beitrag zur Frage der Regulationen im Bienenstaat. Beih Schweiz Bienen Ztg 2, 33-111

Higes, M., Martín-Hernández, R., Garrido-Bailón, E., González-Porto, A.V., García-Palencia, P., Meana, A., del Nozal, M.J., Mayo, R., Bernal, J.L. (2009) Honey bee colony collapse due to Nosema ceranae in professional apiaries. Environ. Microbiol. Rep. 1, 110-113

Hoover, S.E.R., Higo, H.A., Winston, M.L. (2006) Worker honey bee ovary development: seasonal variation and the influence of larval and adult nutrition. J. Comp. Physiol. B. 176, 55-63

Human, H., Nicolson, S.W., Strauss, K., Pirk, C.W.W., Dietemann, V. (2007) Influence of pollen quality on ovarian development in honeybees Apis mellifera scutellata. J. Insect Physiol. 53, 649-655

IAL-Instituto Adolfo Lutz (2008) Métodos físico-químicos para análise de alimentos. IAL, São Paulo [on line] h t t p : / / w w w. i a 1 . s p.g o v. b r / index.php?option $=\% 20 \mathrm{com}$ remository\&Itemid $=0 \&$ func $=$ select\&orderby $=1$. Accessed on 13 June 14

Laemmli, U.K. (1970) Cleavage of structural proteins during assembly of the head of bacteriophage T4. Nature $227,680-685$ 
Loper, G.M., Cohen, A.C. (1987) Amino acid content of dandelion pollen, a honey bee (Hymenoptera: Apidae) nutritional evaluation. J. Econ. Entomol. 80, 14-17

Makert, G.R., Paxton, R.J., Hartfelder, K. (2006) Ovariole number - a predictor of differential reproductive success among worker subfamilies in queenless honeybee (Apis mellifera L) colonies. Behav. Ecol. Sociobiol. 60, $815-825$

Martins, J.R., Nunes, F.M.F., Simões, Z.L.P., Bitondi, M.M.G. (2008) A honeybee storage protein gene, hex 70a, expressed in developing gonads and nutritionally regulated in adult fat body. J. Insect Physiol. 54, 867-877

Martins, J.R., Anhezini, L., Dallacqua, R.P., Simões, Z.L.P., Bitondi, M.M.G. (2011) A honey bee hexamerin, HEX 70a, is likely to play an intranuclear role in developing and mature ovarioles and testioles. PLoS ONE 6, e29006

Maurizio, A. (1954) Pollenernährung und Lebensvorgänge bei der Honigbiene (Apis mellifera L.). Landwirtsch. Jahrb. Schweiz. 245, 115-182

Morse, R., Calderone, N. (2000) The value of honey bee pollination in the United States. Bee Cult. 128, 1-15

Nelson, C.M., Ihle, K., Amdam, G.V., Fondrk, M.K., Page, R.E. (2007) The gene vitellogenin has multiple coordinating effects on social organization. PLoS Biol. 5, 673-677

Nicolson, S.W., Human, H. (2013) Chemical composition of the 'low quality' pollen of sunflower (Helianthus annuus, Asteraceae). Apidologie 44, 144-152

Peng, Y.S., Nasr, M.E., Marston, J.M., Fang, Y. (1985) The digestion of dandelion pollen by adult worker honeybees. Physiol. Entomol. 10, 75-82

Pernal, S.F., Currie, R.W. (2000) Pollen quality of fresh and 1 -year old single pollen diets for worker honey bees (Apis mellifera L). Apidologie 31, 387-409

Pirk, C.W.W., Boodhoo, C., Human, H., Nicolson, S.W. (2010) The importance of protein type and protein to carbohydrate ratio for survival and ovarian activation of caged honeybees (Apis mellifera scutellata). Apidologie 41, 62-72
Potts, S.G., Biesmeijer, J.C., Kremen, C., Neumann, P., Schweiger, O., Kunnin, W.E. (2010) Global pollinator declines: trends, impacts and drivers. Trends Ecol. Evol. 25, 345-353

Praz, C.J., Müller, A., Dorn, S. (2008) Specialized bees fail to develop on non-host pollen: do plants chemically protect their pollen? Ecology 89, 795-804

Rapini, A., Ribeiro, L.R., Lambert, S., Pirani, J.R. (2008) A flora dos campos rupestres da Cadeia do Espinhaço. Megadiversidade 4, 16-24

Roulston, T., Cane, J.H. (2000) Pollen nutritional content and digestibility for animals. Plant Syst. Evol. 222, 187-209

Roulston, T.H., Cane, J.H., Buchmann, S.L. (2000) What governs protein content of pollen: pollinator preferences, pollen-pistil interactions, or phylogeny? Ecol. Monogr. 70, 617-643

Sanchez-Bayo, F., Goka, K. (2014) Pesticide residues and bees - a risk assessment. PLoS ONE 9, e94482

Schmidt, J.O., Thoenes, S.C., Levin, M.D. (1987) Survival of honey bees, Apis mellifera (Hymenoptera: Apidae), fed various pollen sources. J. Econ. Entomol. 80 , 176183

Tasei, J.N., Aupinel, P. (2008) Nutritive value of 15 single pollens and pollen mixes tested on larvae produced by bumblebee workers (Bombus terrestris, Hymenoptera: Apidae). Apidologie 39, 397-409

vanEngelsdorp, D., Evans, J.D., Saegerman, C., Mullin, C., Haubruge, E., Nguyen, B.K., Frazier, M., Frazier, J.L., Cox-Foster, D., Chen, Y., Underwood, R., Tarpy, D.R., Pettis, J.S. (2009) Colony collapse disorder: a descriptive study. PLoS ONE 4, e6841

Velthuis, H.H. (1970) Ovarian development in Apis mellifera worker bees. Entomol. Exp. Appl. 13, 377-394

Williams, N.M. (2003) Use of novel pollen species by specialist and generalist solitary bees (Hymenoptera: Megachilidae). Oecologia 134, 228-237 